\title{
PRIVATIZATION OF AGRICULTURE AFFECTED BY FOREIGNERS
}

\author{
Nenad Avramović ${ }^{1}$, Marko Stanković ${ }^{2}$ \\ *Corresponding authorE-mail: avramovic.n@pravni-fakultet.info
}

A R T I C L E I N F O
Review Article
Received: 30 April 2020
Accepted: 22 August 2020
doi:10.5937/ekoPolj2003029A
UDC 338.43:33.025.28

Keywords:

transition, privatization, agricultural enterprises, privatization agency

JEL: K11, K33, Q10, Q15

\begin{abstract}
A B S T R A C T
The collapse of socialism changed the global picture of the world order and on international plan shifted most of the ex-communist countries of Europe towards Euro-Atlantic integration and membership in the European Union. The economic and social transition of most post-socialist states under the influence of Euro-Atlanticists and domestic pro-Western reformers, is taking place under Washington's consensus. The proposal of international mentors was the urgent privatization, liberalization and decentralization of the economy and society. The aim of the paper is to analyze the privatization of Serbian agriculture according to the shock model, both from the aspect of the application of regulations and the work of institutions, as well as the evaluation of the success of the procedure and privatization effects. Privatization of agricultural enterprises in Serbia has shown numerous weaknesses, which manifest in the work of institutions, inadequate strategy and vision, and in economic terms of stagnation of livestock breeding, reduction of the number of agricultural holdings and increase of unemployment. In this context, the experiences of Germany and China and some European Union countries were presented, which in the choice of transition path were guided primarily by their state and national interests.
\end{abstract}

(C) 2020 EA. All rights reserved.

\section{Introductory remarks}

The social experiment, as most Western analysts call the construction of a socialist society based on the principles of social justice, almost seven decades long, ended, in most countries with a reversible social transformation. The return of ex socialist states to capitalism, in addition to radical changes on the ideological plan, required changes to the political system and the introduction of multiparty parliamentarism and, above all, tectonic ownership and economic transformation.

1 Nenad Avramović, Ph.D., Full professor, Faculty of Law for Commerce and Judiciary in Novi Sad, Geri Karolja Street no. 1, 21000 Novi Sad, Serbia, Phone: +381 21400 499, E-mail: avramovic.n@pravni-fakultet.info, ORCID ID (https://orcid.org/0000-0003-0203-7627)

2 Marko Stanković, Ph.D., Associate professor, Faculty of Law for Commerce and Judiciary in Novi Sad, Geri Karolja Street no. 1, 21000 Novi Sad, Serbia, Phone: +381 21400 499, E-mail: marko.stankovic@pravni-fakultet.info, ORCID ID (https://orcid.org/0000-0002-4238-479X) 
The political metamorphosis of the post-socialist states, with the exception of the Republic of China, had a more or less unique methodological pattern. The wave of overall transitional change, especially in the economy, however, had essentially different national approaches dictated by internal historical determinants, ethnic narratives, and economic heritage. However, the decision to choose the optimal transition path was almost equally influenced by external factors, such as the leading Western countries and their geopolitical sphere of influence and international creators of the global world order, the International Monetary Fund and the World Bank.

Most transition countries, including the Federal Republic of Yugoslavia, and by its disintegration, Serbia, have accepted the rules of the Washington Consensus based on the Atlantic strategy of neoliberal economic development.

In paper authors analyze the process of implementation and the impact of the Washington Agreement reform policies on privatization of the Serbian economy, with special reference to the effects it produced in agricultural production. In this context, the normative legal framework for agricultural privatization, the strategy of agricultural development and the work of state institutions will be presented, as constitutive elements of functioning of the legal state. The overriding goal of this paper is to show the effects of privatization of agricultural land.

In addition to the analytical method, the paper will have a comparative dimension as it will also look at the results of transitional reforms in other countries, which have opted for the choice of another transition path. A comparative analysis of the economic results will confirm or refute the hypothesis that the unconditional application of the Washington "manifest" was the best option for realizing the state and national interests of the Republic of Serbia. At the same time, we will show the extent to which the EuroAtlantic protagonists of the Washington Consensus apply the reform principles in the implementation of their national agricultural policies, and whether the agricultural policy measures of the United States and the European Union and its Member States contribute to liberalizing the world market or protecting the national interests of farmers and their own economies. But first, about the end of the Cold War as a precondition for transition.

\section{About the "Cold War" and the Washington Consensus}

The export of the socialist revolution in the world, advocated by the USSR from the October Revolution until the end of World War II, was based on the Universalist ideology of the second half of the 20th century, replaced by the regional concept of socialism. At the global level, as a consequence of the balance of military potentials and the harmonized division of geopolitical and ideological planetary influence of the East and the West, international relations to the last decade of the second millennium is characterized by the so-called period "of the Cold War". The demolition of the Berlin Wall was a symbolic beginning of the end of socialism as a world process.

Realistically, in a world economic game, socialism laden with bureaucratic procedures was losing the battle with a more efficient and competitive capitalist economy. The 
comparative weaknesses of socialist economy were manifested by the slow growth of the life standard of the population and, in the Western media, by informatively "inflated" restrictions on human rights and freedoms. On the other hand, globalization, logically fueled by the fourth technological revolution, to which neoliberal philosophy further gave wind to the back has further accelerated the transition of the state. Reforming the socialist state and economy was the conditio sine qua non of the further progress of the socialist socioeconomic system.

The collapse of socialism has changed the global picture of the world order, and has shifted Southeast European countries on international plan towards Euro-Atlantic integration and European Union membership, a path that Central European ${ }^{3}$ countries have already pursued. (Avramović, 2019). Of course, this determination was contributed by the self-destructive reaction of the political establishment of the USSR. Actively encouraged and supported by the Western centers of power, the crisis resulted in the dissolution of the Soviet Union, followed by the SFR Yugoslavia and the partition of Czechoslovakia (Andrei et al., 2020). There is a reason to ask: in the history of civilization, and in particular of capitalism, were there any peaceful breaches of the borders by which world powers voluntarily renounced their territories?

Thus, "with the fall of the Berlin Wall at the end of 1989, one of the most significant economic and social transitions with an uncertain outcome began. It was the second economic and social experiment of the 20th century in the post-socialist countries of Eastern Europe and the Western Balkans, guided by the ideas of Western allies and mentors, directly implemented by pro-Western and market-oriented domestic elites. The first social experiment was the October Revolution in Russia, which projected a path to communism almost a century earlier. (Stiglic, 2000).

The bipolar world collapsed and the unipolar hegemon through power soft politics dictated a transition path - a return to capitalism. "And the choice comes down to two basic types: Anglo-Saxon and German-Japanese. The first exists in the US, UK, Canada, Australia and New Zealand, and the second in Germany, the Nordic countries, Japan and "Asian dragons". The Anglo-Saxon pattern is "individualistic capitalism" and German-Japanese "social-market capitalism". In the German-Japanese pattern, the role of the state is greater than in the Anglo-Saxon. Germany is the first in the West in terms of public entity's ownership of share capital. In Japan and the "Asian dragons" the role of the state is so great that these countries are referred to as "guided market" societies by scientists. (Babić, 2015).

In parallel with the organization of the International Monetary Fund in 1989, a project of the Economic Institute for International Economics aimed at solving the problem of indebtedness of Latin American countries, called the Washington Consensus, was realized.

3 Of the 10 countries that became members of the European Union in 2004 through the Big Bang policy, as many as eight were former socialist republics (Latvia, Estonia, Lithuania, Poland, Czech Republic, Slovakia, Hungary and Slovenia), which had previously become full members of the NATO alliance. 
The agreement, which beside the IMF was verified and by the World Bank and the US Treasury, giving it informal international legal validity, envisaged ten reform policies as a solution to the Latin American crisis: a tax policy that favors the wealthy, fiscal discipline, interest rate liberalization, a shift in public spending priorities on economic growth and support for basic health care, education and infrastructure, liberalization of foreign trade and foreign direct investment, competitive exchange rate policy, privatization of public companies, effective protection of property and deregulation or removal of administrative barriers in the area of opening and closing of economic entities.

Through its international support, the Latin American neoliberal reform project has grown from a regional to a universal model applicable (un) planned and to the transition of post-socialist states. Consistent implementation of neoliberal measures of privatization, liberalization and deregulation has meant the state's socialization, and the opening of the market has created conditions for companies from developed Western countries to acquire ownership of domestic businesses under favorable conditions, and then a dominant position in the new market. "The former slogan of the Bolsheviks" the cadres solve everything "- replaces the foreign exchange of rigid economic liberalism," all this will be settled by the private owners." (Popov, 2003).

There was a hurry to implement market logic and build democratic institutions at all costs, fearing from the restoration of the previous system, without considering the opportunities and situation in individual countries. Two fundamental mistakes were made: first, the epochality of the process was not recognized, in the context of the fact that by its inefficiency socialism had lost its historical battle with capitalism, and that there was no place for fear of systemic relapse, and second, the artificial, overnight, transplantation of basic postulates and market institutions democratization are not possible without governments, declining growth rates, tremendous growth in unemployment, distrust of reforms and market democracy, the return of the left to power in the next elections, however not socialism, considering the fact that the reforms could not even be abandoned, but only slowed down. (Josifidis, 2004).

Acceptance of the Anglo-Saxon capitalist model by invasive intervention was generally more acceptable to Euro-Atlantic economic integrationists as well as to domestic corporate governance structures, part of state officials of neo-liberal views, chameleon-colored politicians, and emerging speculators in the interregnum of normative-legal redefinition of state jurisdiction. Ideal opportunity for express entry into the emerging capitalist class.

"The Nomenclature" (the emerging capitalist class - the author's remark) assured the "working people" that it was in his interest. It is enough to identify business owners and "liberate" the market for the prosperity to come. So too did the former "working class" become a worshiper of the Anglo-Saxon pattern, carried by the wings of "folk capitalism" Margaret Thatcher and "high technology, small business" by Ronald Reagan. Members of the former "working class" saw themselves as "small capitalists" and no one in the role of hired workers. Thus, in the "transition" everyone was involved in fraud: the nomenclature appropriated social property on fraud, and the others were deceived or they were deceived and agreed to it. (Babić, 2015). 


\section{Privatization - betrayed expectations}

Thus, the Euro-Atlanticists and domestic insiders who advocate the Washington mantra as a transitional pattern have reached a consensus on the need for privatization following a shock therapy model. Privatization to many ex socialist countries, including in Serbia, was a poorly designed project without a final vision aimed at urgency and the national interests of the state in the background. The objective problem was that in the stateplanned and even self-governed economy, the turnover of enterprises and their market value were not realized in practice. And of course, in the absence of a methodology for assessing the market value of companies, foreigners offered "expensive" services of their agencies and significantly influenced on the control of the sales procedures of the companies they were interested in. Generally, in the absence of a clear state strategy based on the principles of a conscientious businessman, an unjustifiably imposed time limit for the privatization process and lack of competition, the process of ownership transformation of social and state capital into private took place. As a result of high supply and low demand in the privatization market, the selling price was below the real and market value.

Along with the privatization, the liberalization of regulations governing the freedom of movement of goods, services and capital took place, the national treatment was given to foreigners, and the state, by deregulation of customs policy, waived budget revenues while abandoning the protection of domestic economic entities by customs policy measures.

Exposed neoliberal economic policies have led to a series of transition countries leading to the economic devastation of domestic industry as well as agricultural production, and the ensuing negative economic and social consequences chain has taken catastrophic proportions; rising unemployment, restrictions on further growth and development due to the weakening of industries that create new tangible assets and allow exports to the world market, although this was one of the "promised" advantages of opening up national economies. Such economic trends were, as a rule, followed by a dominant focus on imports and trade, that is, commodities of industrialized countries, as well as continued external borrowing. (Jovanović, Eškinja, 2008).

The combination of privatization, liberalization and decentralization should have quickly led, perhaps after a brief transitional recession, to a huge increase in productivity. It was expected that the benefits of the transition would be greater in the long run than in the short term, as old, inefficient machines are replaced and a new generation of entrepreneurs is created. Full integration into the global economy, with all the benefits it will bring, would also follow quickly, if not immediately. (Stiglic, 2018).

Expectations of economic and social revival in most transition countries, and especially in Serbia, remained an unfulfilled wish, and "the transition process, i.e. privatization as its central part, was accompanied by enormous structural breakdowns, a fall in the real social product, a fall in employment, an increase in inflation and a weakening of state institutions, especially the judiciary through the devolution of the law and the rise of corruption and http://ea.bg.ac.rs 
crime." (Obradović, 2017). Regardless of thefacts whether the municip alities have inherited companies - giants with a large 'dead' cap ital, it is necessary for them to orient in atimely manner towards creating a suitable business infrastructure (Lakićević, 2019).

Definitely bad privatization effects of the Serbian economy can be derived from these two data. Namely, although the initial stagnation of the privatized economy is behind us, and for the last three to four years there are positive tendencies "it is evident that Germany and Austria have 3.5 times higher standard of living than, say, Serbia, and that Central European countries, such as the Czech Republic, Hungary, Poland and Slovakia are about 80 percent more developed than Serbia. This is logical given that Serbia's economic growth is at the level of 1976 and is only $78.1 \%$ of that of 1990 . With an average growth rate of 4\%, it will take another seven years to reach 1990 GDP.” (Jakopin, 2018).

\section{Controversies in agricultural privatization}

The aforementioned experiential arguments, and many others of an economic and social character, seriously call into question the axiom: that a privatized market economy on Washington's regulations is more efficient than planned. It is already clear from the above general statement that the privatization of agriculture cannot have a positive sign. "Agriculture has always been one of the most important branches of the Serbian economy, but its importance for Serbia has grown tremendously after the collapse of industrial production caused by sanctions and wrongful privatization. The events in and around agriculture are crucial to the state of the Serbian economy. (Popov, 2013).

According to the size and structure of available agricultural land, the Republic of Serbia is one of the European countries with favorable land resources, since it has 0.7 hectares of agricultural, or 0.46 hectares of arable land per capita. At the same time, the ratio of arable land and permanent crops to meadows and pastures is more favorable than other European countries (71\% : 29\%). (Agriculture Strategy, 2014). The existing statistical classification of settlements is most often used for defining rural areas (Sagić, 2019). Agricultural land accounts for $60 \%$ of the total territory of the Republic of Serbia, while that percentage in Vojvodina is as high as $82 \%$ and is mostly of high quality arable land.

The Republic of Serbia has 5.06 million hectares of agricultural land, of which $71 \%$ of the area is intensively used (in the form of arable land, orchards and vineyards), while $29 \%$ of the agricultural area consists of natural grasslands (meadows and pastures). The dominant agricultural area of 3.3 million hectares or $65 \%$ is used as arable land, of which about 7\% is not used annually for agricultural production. (Agriculture Strategy, 2014). However, the lack of economic growth and, consequently, the gross domestic product, which is lower than three decades ago, undoubtedly indicate the insufficient effects of agricultural production at the country level. How much and what impact on the economic indicators has the privatization of agricultural combined plants had?

Privatization of agricultural companies in Serbia was carried out in accordance with the Privatization Act of 2001, without having previously regulated the status of state and cooperative property, which was used and managed by socially owned enterprises. The 
main problem was the fact that buyers of social capital in privatized agricultural entities in real estate cadastres changed their form from social and state to private property only upon confirmation of the Privatization Agency that they fulfilled the obligations stipulated in the privatization contract. And, in accordance with the Law on Conversion of Social Property on Agricultural Land into Other Forms of Ownership (Official Gazette of RS, 1992) and the Instruction on the Method and Procedure for Determination and Registration of Agricultural Land in Social Property Used by Legal Entities (Official Gazette of RS, 1994) obligation to register and record agricultural land that they also use to make appropriate changes to the public records on real estate records by 31 December 1997. on special forms, which with the complete documentation on the legal basis of land use are submitted to the RGA. The Real Estate Cadastre Service, which carried out the check and verification of the facts stated in the form, was obliged to take ex officio the implementation of the changes made on the real estate and to submit to the Ministry of Agriculture data on the ownership of the land. (Anti-Corruption Council, 2017).

Therefore, the economic operator could not transform the state and social property into private property, before listing into the agricultural land and registering and updating it in the real estate Cadastre. The Cadastre would inform the Ministry of Agriculture about these facts, which would then, before conducting the privatization process, issue a certificate on the completed census, records and status of agricultural land to the Privatization Agency, which had the responsibility of conducting the privatization process.

Of the 148 privatizations of agricultural plants, carried out from 2002 to 2015 in only 84 cases or less than 57\%, analyzed by the Anti-Corruption Alliance, the status of ownership of agricultural land is clearly determined. The legal validity of the privatizations carried out on the basis of the above would be highly questionable in over 43 percent.

The legal basis for the transfer of state, cooperative and even social property is also debatable. "For example, there are opinions that agricultural land as a public good of public interest could not and cannot be subject of privatization." (Popov, 2013). Namely, land with state and co-operative ownership has its title holder, and agricultural combines on the same had only the right of use, but not the right of ownership that could be transferred to new owners. Admittedly, in the period of self-governing socialism, cooperative property was transformed into social, and with the restoration of the cooperative, its legal status was largely not restituted, so it was treated as social in the privatization process. A similar situation is with social property, which was an expression of the socialist socioeconomic system of the sui generis institute and the abolishing factor of alienation of the working class from the means of production, so in the earlier philosophical-ideological concept its privatization would be heresy. To make this legal galimatias an even more complex privatization concept, it is contrary to the basic legal principle in the derivative, translational acquisition of rights - nemo plus iuris ad alium transferre potest quam ipse habet. ${ }^{4}$

4 No one can transfer to another more right than he or she has.

http://ea.bg.ac.rs 
There is no doubt that the privatization scenario of agricultural combines was conceived, interpreted and implemented by the neoliberal shock matrix of international mentors and the ruling notion that state ownership of land is a recurrence of past times. The protagonist of such views, of course, was the Privatization Agency. However, the Privatization Agency also sold the land over which they were entitled to use by selling the combines. The Agency claims the opposite - it never sold the land, but solely the capital of an enterprise, that is, the entire enterprise! This is where the problem arises because the value of the land was not in the balance sheets and it did not enter into the valuation of the firm. However, the price was also built through the land which was obtained for use. (Gulan, 2015).

It is clear that the privatization of the economy was a politically delicate, economically complex, legally complicated, socially frustrating and historically retrograde process. Negative experiences in the privatization of industrial enterprises in the Serbian economy and international sanctions were not enough warning to draw up a strategic concept of privatization of agrarian, which would include the widest possible range of the agricultural population and promote the rural household. Instead, "in the context of such privatization there was the formation of huge land holdings and land ownership structures that do not exist in the European Union, most reminiscent of the situation in Imperial Russia in pre-revolutionary times with all the attendant socioeconomic consequences." (Popov, 2013).

\section{Instead of a conclusion}

Instead of privatization of agricultural land as a step towards establishing an agricultural model on which the family farm will be integrated into the renewed cooperative system, as it exists in the countries of the European Union, the transition process went towards the creation of huge agricultural estates, which are, per se, oriented towards crop production and seasonal employment. The operational implementer of such privatization was the Privatization Agency, which acted as an independent body within the Ministry of Economy. The accession of the ex socialist economy of the Democratic Republic of Germany to the economy of the Federal Republic 1990 opened up the problem of its integration into the economic system of the unique state. And how the privatization of the DDR, the world's tenth largest economy, was solved by the Germans?

In most countries of Eastern and Central Europe, this process took place through market mechanisms (through auctions, vouchers, capital markets, various funds...) The Germans chose for themselves a different path. He ran through a state agency (THA), formed before the unification, which through state decree became the owner of all state-owned enterprises DDR. Thus, in order for privatization to have a real economic rationale, it was started by a decree on nationalization of 85 percent of the economy sector, with a total of four million employees and 40 percent of the land fund. The Agency employed 4,500 professionals in the headquarters and numerous regional departments. In every privately owned enterprise, at least as many employees worked directly with THA, resulting in an estimated figure of nine thousand experts - government officials who were specialists and 
knowledgeable about the economic practices and the impact of individual businesses on local and regional communities. Finally, the deadlines for taking all the necessary actions were relatively comfortable. The original plan was for them to be up to five years old. Even such a well-conceived venture, backed by the funds of one of the most developed economies in the world and driven by typically Prussian precision, could not have gone without great disappointments. (Bulatović, 2012).

Unlike the Federal Republic of Germany, despite transitional examples from other countries, such as China, where privatization of agricultural enterprises has not been completed, as well as political transition, the Federal Republic of Yugoslavia or Serbia has chosen the expedited privatization of agricultural combines, without having a strategic vision of a model that would lead to nationwide prosperity. The institutions of the system, all in transition, and some, such as the Privatization Agency, without experience and vision, often acted in the shadow of the staff and instructions of international factors. And, in order to build a neoliberal state and ensure the rule of law, institutions must outgrow their personal composition and consistently respect the legal order. The consequences of the privatization of agrarians in Serbia have a negative sign and are manifested through: decrease in the number of agricultural holdings, extinguishing and abandonment of villages, stagnation of livestock production, increase in unemployment, a large number of agricultural professionals without jobs, inadequate subsidy policy and underdeveloped cooperatives... Thereby, the additional doubt to the legal validity of the privatization left the suspicion that for most of the time of the privatization, no state institution, not even the Privatization Agency, had an obligation to check the origin of the money used for the privatization. On the other hand, agricultural policy practice in France, Germany, Austria and other EU countries is conceptualized on other grounds.

Therefore, it is no wonder that, for example, the Netherlands, which has less arable land than Serbia as many as three times, simultaneously exports over $\$ 70$ billion per year in agriculture, while exports of Serbia's farmers is a little over $\$ 3$ billion. At the same time, for example, there is a special bank in China that deals with rural development, and it is the most populous country in the world, while Serbia does not have a bank in charge of agricultural production. On the other hand, agriculture and food industry of Serbia participates in the gross domestic product of the country with over twenty percent.

For the absurd to be complete, swift and complete privatization was carried out at the behest of monetarists from the International Monetary Fund and the World Bank. The proposal was also made to Slovenians, but the creator of Slovenian privatization, Jože Mencinger, replied: "Do you want to teach us how to destroy our economy so that it can be better later?"

\section{Conflict of interests}

The authors declare no conflict of interest. 


\section{References}

1. Andrei, J. V., Popescu, G. H., Nica, E., \& Chivu, L. (2020). The impact of agricultural performance on foreign trade concentration and competitiveness: empirical evidence from Romanian agriculture. Journal of Business Economics and Management, 21(2), 317-343. doi: https://doi.org/10.3846/jbem.2020.11988

2. Avramović, N. (2019). Impact of neoliberal transition and EU policy on the economic framework of the Republic of Serbia, Proceedings of the International Scientific Conference, Faculty of Law, University Business Academy in Novi Sad, Novi Sad, Serbia, 29-41.

3. Babić, SB. (2015). Cur de asini umbra disseramus? Economic Ideas and Practice, 16-17, 143-174.

4. Bulatović, M. (2012). Sorrow of Criminal Privatization, Retrieved from http:// www.pecat.co.rs/2012/07/jadi-zlocinacke-privatizacije/ (Janary 12, 2020).

5. Gulan, B. (2015). Privatization in Agrarian Policy: Whose Country is Ours, Retrieved from http://www.politika.rs//sr/clanak/320052/Privatizacija-u-agrarucija-je-nasa-zemlja (January 10, 2020).

6. Jakopin, E. (2018). Economic Growth and Institutional Transition of the Republic of Serbia. Economic Horizons, 20(2), 95-108. doi: https://doi.org/10.5937/ ekonhor1802095J

7. Josifidis, K. (2004). Neoliberalism - Fate or Choice of Lifestyle (I) in Transition. Economic Construction, 1-2, 12-13.

8. Jovanović, M., \& Eškinja, I. (2008). Some aspects of neoliberalism in the world economy. Proceedings of the Faculty of Law, University of Rijeka, 29(2), 950-968.

9. Law on Conversion of Social Property on Agricultural Land into Other Ownership Forms, Official Gazette RS, 49 / 92,54 / 96 and 62/2006-Dr Law, Belgrade, Serbia.

10. Lakićević, M., Žarevac Bošković M. (2019). Tourism as a catalyst for local development in the municipality of Vrnjačka Banja, In: Cvijanović D. et al. (Eds.) The Fourth International Scientific Conference: Tourism in Funcion of Development of the Republic of Serbia - Tourism as a Generator of Employment (pp. 469-485), 30 may - 1 june, Vrnjačka Banja, Serbia: University of Kragujevac - Faculty of Hotel Management and Tourism.

11. Obradović, N. (2017). Chronicle of the Transitional Cemetery. New Serbian Political Thought, 1, 43-56.

12. Popov, Đ. (2013). The Impact of Transition on the State of the Serbian Economy. Proceedings of the Faculty of Law in Novi Sad, 47(1), 28-37.

13. Popov, N. (2003). Work - punishment and reward in Living from Work, edited by Lidija Jovetić. 
14. Anti-Corruption Council. (2017). Privatization and disposal of publicly owned agricultural land of the Republic of Serbia, 72 No: 023-13035 / 2017, Government of the Republic of Serbia, Belgrade, Serbia.

15. Sagić, Z., Lakićević, M., Durkalić, D. (2019). Analysis of turnover in a rural tourism destination - Case study of Ivanjica. Economics of Agriculture, 66(3), 835850. doi: https://doi.org/10.5937/ekoPolj1903835S

16. Stiglic, J. (2018). Globalization and its Contradictions, Miba Books, 301, Belgrade, Serbia.

17. Stiglic, J. (2000). Wilted Reforms? Ten Years of Transition (World Bank Annual Conference on Development Economics 1999), 27, Washington. USA.

18. Strategy of agriculture and rural development of the Republic of Serbia for the period 2014-2024., Official Gazette RS 85/2014, 2, Belgrade, Serbia. 